\title{
George Herbert Mead on Hawaii: an Introduction
}

\author{
Jean-François Côté ${ }^{1}$
}

Published online: 3 June 2016

(C) Springer Science+Business Media New York 2016

George Herbert Mead's relation to Hawaii was primarily personal; his wife, Helen Castle Mead, came from a prominent family of plantation owners in Honolulu. Mead met Helen while studying in Germany in the late 1880s with his friend Henry Castle Helen's brother. After they married in 1891 and settled in Ann Arbor, where Mead was hired as a professor of philosophy at the University of Michigan before moving to the University of Chicago in 1894, George Herbert and Helen travelled to Hawaii several times to visit family, and got involved in local social, political, and cultural life. Daniel R. Huebner was the first scholar to draw attention to and extensively document this relation between Mead and Hawaii, devoting a full chapter to it in his excellent recent book, Becoming Mead: The Social Process of Academic Knowledge. ${ }^{1}$ From Huebner we get a clear, highly instructive, and very well documented view of the ways Mead immersed himself, both biographically and intellectually, in Hawaii's history, at this intense period prior to, and just following, the Islands' annexation by the United States in 1898.

With respect to this historical and political event it is worth paying attention to the two pieces published here: the first an article Mead wrote for the Chicago Tribune, originally published on January 22, 1898; the second a paper Mead wrote as a speech for the National Land Farm Congress in Chicago, delivered on November 18, 1909, and published here for the first time. These two texts present the personal views that Mead held regarding Hawaii and its relation to the United States, and feature a strong bias on the issue. But more importantly, they also both represent the kind of sociological analysis that characterized Mead's position at the time. Indeed, one gets an idea of what sociology meant for him at the turn of the century, that is, during a period when the discipline was first being formed, and before the "Chicago School" of sociology

${ }^{1}$ See, in particular, Chapter 3, "Hawaiian Sojourns," (pp. 62-82). The present introduction relies extensively on the information contained in this chapter.

Jean-François Côté

cote.jean-francois@uqam.ca

1 Department of Sociology, University of Quebec at Montreal, Montréal, QC H3C 3P8, Canada 
would come to represent a disciplinary orientation - albeit in disputable, if not conflictual, affiliation with Mead. ${ }^{2}$ In both texts, then, we find examples of typical Meadian sociological insight about the full organization of society, both in terms of its international ramifications and internal composition. ${ }^{3}$ Through an analysis of the Hawaiian situation, particularly in the first piece from 1898, Mead stresses that the Islands' political autonomy guarantees a successful annexation by the United States, while in the second piece, he strongly argues for the "colonization" of Hawaii by autonomous farmers from the continental United States. These issues are quite interesting in themselves, but they also highlight, together with his own sociological vision, Mead's political philosophy.

In the first piece, "Hawaiians Are Fit," Mead's argument revolves around political autonomy, or the "self-ruling capacity of the population in the islands." Starting with the apparent paradox, which Mead calls a "contradiction," of a self-ruling population demanding annexation by a larger unit, his line of reasoning links the specific situation of a small autonomous political unit requiring a larger one for its own stability. Mead establishes a parallel with the internal situation in the United States, on the one hand, and on the other hand with the historical example of Ancient Greece, which he examined in another context (Côté 2013), showing the scope of his views regarding contemporary society in its international dimension. ${ }^{4}$ This also has significant consequences for the internal composition of relations among different groups in Hawaiian society: "Natives" who encountered Western development, Oriental migrants, and the merchant and "mechanic" classes searching for economic opportunities by establishing permanent market links with the continental United States.

Mead's perspective is important to consider on many levels. First, it provides a key to the understanding of his view of the world at the threshold of the twentieth century, based on a complex set of relations that prefigured the organization of an international society that Mead considered to be the real foundation for all world populations. (This will become particularly clear with regards to the First World War, which we will return to below.) Specifically, he points out that the stability of a society depends on its capacity to include "the activities that represent all sides of humanity." Second, it shows how Mead positions the evolution of human society in its most recent form, which depends on the institutionalization of a capacity for selftransformation embedded in its political institutions (Côté 2015). ${ }^{5}$ Third, it places "autonomy," or self-government, at the centre of political philosophy.

\footnotetext{
${ }^{2}$ The debates surrounding the problematic affiliation of the "Chicago School" with Mead's thought have been raging for decades, starting with Lewis and Smith (1980). It is still not clear to what extent a Meadian sociology, or a sociology strongly inspired by Mead, overlaps with the sociological developments associated with the Chicago School, but recent efforts at distinguishing Blumer's symbolic interactionism from Mead have provided some clues in this direction.

${ }^{3}$ I develop this sociological component of Mead's thought further in George Herbert Mead's Concept of Society: A Critical Reconstruction (2015).

${ }^{4}$ On Mead's view on Ancient Greece, see my 2013 article, "George Herbert Mead on Ancient Greek Society: An Introduction." The manuscripts on Ancient Greek society were probably written in the mid-1890s, prior to this article on Hawaii, but the references in this article clearly demonstrate this link in Mead's thought, particularly with respect to the political instability of smaller political units like the Ancient Greek city-states. ${ }^{5}$ On this, see also George Herbert Mead, "The Problem of Society - How We Become Selves," (1936): 360385 .
} 
These perspectives in themselves deserve much wider and deeper attention, since they can greatly complement and enhance Mead's well-known views on the ontogenetic development of individual selves in relation to social organization. Passing from individual integration to the free activities of "play," and then to the structured and ruled activities of the "game" as phases of socialization, Mead's notion of ontogenetic development should explicitly find its culmination in "autonomy," the capacity of giving oneself its own rules - the crowning embodiment of "free activity," and even freedom itself, in its societal definition. Autonomy should thus stand as the most important aspect of the ontogenetic development of individuals, and as such the aim of social organization in its phylogenetic development, in its capacity to provide both society and individuals a self-guiding rule. So it is somewhat strange that Mead did not insist on this wider point in his writings (as he did for "play" and "game"), by linking autonomous individuals to an autonomous society as the two corresponding ideals of his political philosophy. ${ }^{6}$ But this does appear clearly in his 1898 article, where Mead argues that only because Hawaiian society had developed such a capacity, both in its citizens (or parts of its citizenry) and institutions (schools, churches, and elected government), can it be said to be "ready" to join the United States. There is of course a strong preference here as to what kind of social and cultural backgrounds are needed in order to face the requirements of self-government, as Mead points out when he writes that it is essentially the presence of missionaries from the United States to Hawaii in the early decades of the nineteenth century that paved the way for such a development. And it is also clear that the economic interests of the descendants of these missionaries are at stake in the annexation project, as Mead shows when he argues for a type of economic development in Hawaii based on a mechanical (and even scientific) agriculture that mainly relies on owners who are locally present (as opposed to other English colonial developments, which rely on "absent owners"). Among the views defended by Mead about the contributions of missionaries and their descendants (of which the Castles were eminent representatives) was their dedication to the betterment of social conditions of the Hawaiian population, for both Indigenous people and immigrants; for the former particularly, whose fate was doomed, according to Mead, since Western civilization set foot on Hawaiian islands, colonization by missionaries, and further military action by the U.S government, provided a way of getting rid of their traditional monarchical system (by deposing the queen Lili'uokalani and establishing a provisional government in 1893) - a contentious point to be sure, given the context of the annexation itself, which was attended by a series of events marked by intense political turmoil and long-standing controversies. ${ }^{7}$ These combined factors converge towards a global picture of

\footnotetext{
6 The notion of "autonomy" became the central aspect of the late Enlightenment philosophy, from Kant to Hegel, since it prompted both the individual to "make use of reason," and society to give itself a proper constitution. Mead followed the continental political philosophy in this, in taking the French and American revolutions as the true symbols of a decisive historical evolution - see G.H. Mead (1936: 25-152).

${ }^{7}$ On these issues, from a more recent perspective, see Noenoe Silva, Aloha Betrayed: Native Hawaiian Resistance to American Colonialism (2004); Tom Coffman, Nation Within: The History of the American Occupation of Hawai' i (2009); and Julien Go, American Empire and the Politics of Meaning: Elite Political Cultures in the Philippines and the Puerto Rico during U.S. Colonialism (2008).
} 
Mead's position, one largely favourable towards U.S. annexation of Hawaii, thus raising questions about the kind of political order being deployed in this context.

What is striking here is the way that notions of nationalism, imperialism, internationalism, and even cosmopolitanism are all enmeshed with one another; they were not yet well differentiated and defined in Mead's thought, and would remain so for some time. (The First World War would provide Mead with the occasion to clarify their imbrication to some extent, as he published several articles in the Chicago Tribune that discuss his views on national and international politics aimed at a much wider public, instead of particular groups or specialized circles. ${ }^{8}$ ) This situation is not surprising, given the coincidental rise of imperialism within nationalism in the United States in those years. 1898 was also the year when the Spanish-American War broke out, and it became clear that the Monroe doctrine was being implemented to its full measure, offering "protection" to nations in the American hemisphere against European powers with respect to their former colonies, while initiating U.S. "protectorates" that would themselves turn into colonial occupations (in Cuba and Puerto Rico, but also in Guam and the Philippines). The rise of the United States as a new power on the world stage greatly marked this era, signalling the implementation of a foreign policy that would deeply affect societies around the world - and particularly the societies within the Americas. (This included later occupations, invasions, and interventions in Haïti, Nicaragua, and Columbia in the early twentieth century, according to a set of foreign policies that evolved from the "big stick" policy of Theodor Roosevelt in the 1920s and F.D.R.'s "good neighbour" policy in the 1930s, to the hard-line Cold-War policies following the Second World War.) And while Mead was prompt to condemn German imperialism during the First World War, he remained apparently silent about all those occasions when the United States intervened within its hemispheric context. This silence in itself does not tell everything about Mead's political philosophy, but it might help us to understand the kind of national and international society he had in mind for the contemporary world. The second piece reproduced here can help illuminate these issues.

The paper Mead delivered on November 18, 1909 to the National Land Farm Congress in Chicago is quite clear on the issue of "colonization." 9 This is not a surprise, given the group targeted by the speech, and given the open call, if not exhortation, to

\footnotetext{
${ }^{8}$ On Mead's views on the First World War, see Mary Jo Deegan, War, and Society: George Herbert Mead's Macrosociology (2008). I am pointing out here the relative infrequency of using media outlets like the Chicago Tribune for reaching the public, as opposed to speeches Mead addressed to various groups, or articles that he published in scholarly journals; Mead only wrote for newspapers when topics related to "national politics" were at stake.

${ }^{9}$ As Huebner remarks on the context of this speech: "Mead not only spoke as an authority in Hawaii, but also spoke on behalf of Hawaii in an official capacity on at least one occasion. A National Farm Land Congress was called to discuss the various issues of agriculture in the United States and suggest new national agricultural policy in November 1909 in Chicago, and delegates were appointed form the various states and territories of the country to attend. Governor Walter F. Frear officially named Mead the head delegate for Hawaii and his personal representative to that convention" (p. 75). Acting as an official representative, Mead spoke from the "Hawaiian-American" point of view, making extensive use of information taken from "pamphlet material prepared by the Hawaii Promotion Committee" (Huebner 2014: 267, note 41).
} 
farmers in the United States to join the effort to further colonize Hawaii. The first sentence of the speech states the case unequivocally: Hawaii represents, as Mead puts it, "America's oldest and indeed only colony in the proper sense of that term." About one decade after annexation, through which "the unity of sentiment and institution which existed between these islands and mainland was realized externally" (my emphasis), the net result has been the achievement of a State where "[ $t]$ he community is American." The affirmation of this result is ironically confirmed by Mead's enumeration of the different nationalities present in Hawaii (in order of population size Japanese, Chinese, Hawaiian, Portuguese, Korean, Spanish and Puerto Ricans), while the number of "Americans" was estimated at 13,000, thus placing them after the Portuguese and before the Koreans. That the Japanese, Chinese, and Hawaiians combined represent ten times the American population doesn't seem to matter much here, as Mead expresses the idea that not everyone is equally fit for undertaking the economic development of Hawaii - the "Latin race" (Portuguese and Spanish) make good labourers, and the "Orientals" (Chinese and Japanese) are better workers, in his view, than the Native Hawaiians. While presenting in some detail the possibilities and advantages autonomous farmers would gain by going to Hawaii, Mead wants to encourage the peopling of the Islands with more individuals from the United States, in order, as the last paragraph makes clear, to "roll back the tide of Oriental population which has threatened to take possession" of Hawaii, which should be "still more occupied by Americans."

As it stands, this position conveys a strategic perspective on the international situation, where the United States extends its own borders way out into the Pacific, and in doing so secures this extended territory for economic development - similar to the motivation that prevailed during the nineteenth-century continental expansion westward. Mead's position seems to resonate with the famous thesis of Frederic Jackson Turner's "The Significance of the Frontier in American History," 10 and is also coherent with the then-prevailing view that the United States represents an international society. On the one hand, the U.S. was a society deeply involved, externally, in global multi-national relations (in itself, a cosmopolitan task), whereas on the other hand, internally it represents a society that has integrated people from all over the world under one roof. The "nation of nations," as Woodrow Wilson would come to call it in the context of promoting the League of Nations after the Treaty of Versailles, was being defined according to a brand of nationalism that could accommodate itself with internationalism, if not with its own type of imperialism. For its part, cosmopolitanism, as a universal form of social relations permeating every individual consciousness with respect to a world order belonging to all, would be left to those like Mead (2015) to give it an approximate definition through the idea that "communication" as such was the new force through which it could be formulated - in its widest and deepest symbolic implications.

\footnotetext{
${ }^{10}$ Huebner (2014: 65) mentions that Mead attended Turner's address in 1911, much after it was first delivered at the World's Columbian Exposition in Chicago in 1893 - but he could also have been acquainted with it in the interval.
} 


\section{References}

Coffman, T. (2009). Nation within: The history of the American occupation of Hawai'i. Kibet: Koa Books. Côté, J.-F. (2013). George Herbert Mead on Ancient Greek society: an introduction. Canadian Journal of Sociology, 38(3), 383-405.

Côté, J.-F. (2015). George Herbert Mead's concept of society: A critical reconstruction. Boulder: Co. Paradigm Publisher.

Deegan, M. J. (2008). Self, war, and society: George Herbert Mead's macrosociology. New Brunswick: Transaction Publishers.

Go, J. (2008). American empire and the politics of meaning: Elite political cultures in the Philippines and the Puerto Rico during U.S. Colonialism. Durham: Duke University Press.

Huebner, D. R. (2014). Becoming Mead. The social process of academic knowledge. Chicago: University of Chicago Press.

Lewis, J. D., \& Smith, R. L. (1980). American sociology and pragmatism: Mead, Chicago sociology, and symbolic interaction. Chicago: Chicago, University of Chicago Press.

Mead, G.H. (2015). Mind, Self and Society, edited by Charles Morris, annotated by Hans Joas and Daniel R. Huebner, Chicago: University of Chicago Press.

Mead, G. H. (1936). Movements of thought in the nineteenth century. Chicago: University of Chicago Press.

Silva, N. K. (2004). Aloha betrayed: Native Hawaiian resistance to american colonialism. Durham: Duke University Press. 